\title{
THE INFLUENCE OF COUNTRY OF ORIGIN TOWARDS BRAND EQUITY DIMENSIONS AND PURCHASE INTENTION OF CHINESE SMARTPHONE BRAND
}

\author{
Edy Kalme Haganta Sinulingga ${ }^{{ }^{*}}$, Jean Richard Jokhu ${ }^{2}$ \\ ${ }^{1}$ Jurusan Manajemen, Universitas Presiden Bekasi \\ Email: hagasinulinggaars@gmail.com \\ ${ }^{2}$ Jurusan Managemen, Universitas President Bekasi \\ Email: jean.richard@president.ac.id \\ *penulis korespondensi
}

Masuk : 12-04-2021, revisi: 02-06-2021, diterima untuk diterbitkan : 10-06-2021

\begin{abstract}
ABSTRAK
Penelitian ini bertujuan untuk mengetahui: pengaruh negara asal terhadap dimensi ekuitas merek dan niat beli merek smartphone Cina yaitu Xiaomi. Variabel yang digunakan dalam penelitian ini adalah: negara asal, kesadaran merek, asosiasi merek, loyalitas merek, persepsi kualitas, dan niat beli. Penelitian ini menggunakan metode kuantitatif dengan metode convenience sampling. Pengumpulan data dalam penelitian ini menggunakan data primer dengan menyebarkan kuesioner kepada 302 responden yang pernah menggunakan smartphone chines. Teknik analisis data dalam penelitian ini menggunakan Structural Equation Model (SEM) dengan software SmartPLS 3.0. Berdasarkan analisis yang telah dilakukan, hasil penelitian ini menunjukkan (1) terdapat pengaruh yang signifikan dari negara asal terhadap kesadaran merek, asosiasi merek, loyalitas merek dan persepsi kualitas. (2) Terdapat pengaruh yang signifikan antara kesadaran merek, loyalitas merek, dan persepsi kualitas terhadap niat beli. (3) Tidak terdapat pengaruh yang signifikan antara negara asal dan asosiasi merek terhadap niat beli.
\end{abstract}

Kata Kunci: Negara Asal, Niat Beli, Ekuitas Merek, Merek Smartphone China

\begin{abstract}
This study aimed to find out: the influence of country of origin towards brand equity dimensions and purchase intention of Chinese smartphone brand which is Xiaomi. The variables that used in this study are: country of origin, brand awareness, brand association, brand loyalty, perceived quality, and purchase intention. This study used quantitative methods with convenience sampling method. Data collection in this study used primary data by distributing a questionnaire to 302 respondents who are ever use chines smartphone. The data analysis technique in this study used Structural Equation Model (SEM) with SmartPLS 3.0 software. Based on the analysis that has been done, the result of this study shows (1) there are significant influence of country of origin on brand awareness, brand association, brand loyalty and perceived quality. (2) There are significant influence of brand awareness, brand loyalty, and perceived quality towards purchase intention. (3) There are no significant influence of country of origin and brand association towards purchase intention.
\end{abstract}

Keywords: Country of Origin, Purchase Intention, Brand Equity, Chinese Smartphone Brand

\section{INTRODUCTION}

In this globalization era, geographical boundaries are no longer an obstacle to establishing communication between individuals. People can know information, news, and situation on other continents in a very short amount of time. This situation occurs because information and technology are growing rapidly. The fastest development today is the use of the internet network called smartphones. Smartphones are phones with high-level functions, and sometimes their functions are similar to computers (Computerhope.com, 2021). Smartphones today have become a basic necessity. People use their phones for almost all of their activities like socializing, reading, watching videos, listening to music, even making online transaction. Therefore, having a smartphone is important for everyone. 
According to Statista.com, smartphone users worldwide is increasing year after year. There are 3.3 billion of 7.51 billion people on earth recorded as smartphone users in 2019. It means that $43.9 \%$ of the world population already become a smartphone market and still potentially increasing. This amount of market has triggered the long-establish and new information and technology companies to compete in selling their best product. This phenomenon also affects Indonesia. According to Countriestoday.com, in 2018, Indonesia has become the 6th Country with the most smartphone users in the world. A large number of smartphone users in Indonesia drives a lot of technology and telecommunication companies to enter the Indonesian smartphone market competition.

Indonesia's mobile phone market has several big brands from several countries of origin. Counterpoint issued a recent report that recorded the movement of smartphones in Indonesia during the second quarter of 2020. The five smartphone brands with the most sales during April - June 2020 are Vivo, Oppo, Samsung, Xiaomi, and Realme. These five smartphone brands dominate more than $90 \%$ of total sales during the quarter in Indonesia. Vivo leads the market with a $21.2 \%$ of market share in Q2 2020, followed by Oppo with $20.6 \%$ and Samsung with $19.6 \%$. Chinese mobile phone leads Indonesia's smartphone market with $73.3 \%$ combined. This data is also supported by research conducted by IDC.com that stated Chinese mobile phone has $79.1 \%$ of Indonesia mobile phone market share.

The need and demand for smartphones have created intense competition between smartphone manufacturers from various countries. And this creates more and more options for buyers to choose from. Chinese manufacturers often have a poor perception of their brand and the quality of their products (Kreppel \& Holtbrugge, 2012). China has started positive growth as the world's top producer, but product quality is still considered low (Yunus \& Rashid, 2016). Wicaksana (2018) stated that Indonesian customer perception of a non-Chinese product is better than Chinese product. But this is not reflected in the market share chart issued by counterpointresearch.com, where 4 Chinese smartphone brands are in the top 5 brands that have the largest market in Indonesia with $73.3 \%$ of market share. This situation is also contradictive with previous research which Berlianto (2019) said that COO has a significant effect on brand equity and purchasing intention where people tend to buy a product from the Country that has a positive image rather than a product from the Country that has a deficient image, but Chinese products are still salable in the Indonesian market.

Besides Country of origin, a brand is an important factor for customers in choosing which product they will buy. According to the American marketing association in Kotler and Keller (2012), brands are designed to see a product or service or a group of sellers and distinguish it from its competitors. One way the company uses to introduce its brand and measure the presence of a brand in the market is known by brand equity. Kotler and Keller (2012) characterize brand equity as an additional incentive for goods and service that is pictured in how consumers think, feel, and behave on the brand and things related to the brand. According to Alam (2018), consumer-based brand equity is a multidimensional concept. Brand awareness, brand loyalty, perceived quality, and brand association are all aspects of brand equity. Menon (2016) shows that active brand equity can generate greater revenue, reduce costs, and increase profits, so that consumer-based brand equity is very important in brand management.

Based on the foregoing, the authors have used brand equity to explain the relationship between Country of origin and purchase intention. The theory of brand equity from Keller (1993) used for this research. Research in understanding the role of Country of origin toward brand equity 
and purchase intention. The authors found a limited study about brand equity from a Country of origin perspective (Menon, 2016; Gabriella \& Sonny, 2021). Therefore this study needs to examine the influence of the Country of origin on the brand equity scale and the influence of the brand equity scale on the purchase intention.

\section{LITERATURE REVIEW Purchase Intention}

Purchase intention is the desire of consumers to purchase or prefer the products to buy based on their need. Purchase intention may be defined as the eagerness to buy, and this is part of the mechanism leading to a purchase action made by a consumer. According to Artaji (2014), purchase intention is one type of motivation or intrinsic motivation that can encourage someone to be spontaneous, fair, easy, and without compulsive attention and selectively make a product purchase decision. Purchase intention is the willingness of a customer to purchase goods or services. When consumers get enough information about the product or service they want, the purchase intention will appear (Aryani \& Usman, 2019; Almaihamed, 2019). Purchase intention is a factor that can influence the consumer's decision to buy the product.

\section{Brand Equity}

Brand equity is seen as a crucial marketing tool that can affect the success of the business (Alam et al., 2018). Karina (2015) argues that brand equity is connected to the tangible and intangible effect of a brand's negative or positive impact on the brand, its products and services, and the focus comes from the knowledge, perceptions, and experiences of customers about the company. There are several theories and tools that can measure a company's brand equity. Aaker (1991) and Keller (1993) proposed a method to measure consumer-based brand equity based on the four dimensions, including brand awareness, brand association, brand loyalty, and perceived quality (Menon, 2016; Manojkumar et al., 2018).

\section{Brand Awareness}

According to Sanfilipo (2017), consumers first need to be conscious of the brand in order to establish a collection of connections linked to the brand. The consumers can remember the brand when a need is evoked through brand recall or remember the need when the brand is evoked through brand recognition. In Sanfilipo (2017), Aaker notes that brand awareness is the willingness of prospective customers to identify or remember that a brand is in a certain category of product. Meanwhile, Kotler and Keller (2012) explain that Brand awareness is the potential of customers to distinguish brands in any cases, which is depicted in their brand identification or recall performance. In some industries that have common product categories, awareness provides a sustainable competitive distinction.

\section{Brand Association}

Based on their knowledge of the brand, consumers can evaluate the brand attributes and benefits. Defined as "anything related to brand memory" (Aaker, 1991), brand associations embrace the meaning of brands for consumers (Keller, 1993). According to Kotler and Keller (2012), the brand association is all the reflections, sentiments, understandings, images, encounters, beliefs, perspectives, etc., associated with a brand that connected to a brand node.

\section{Brand Loyalty}

According to Alam (2018), an important part of brand equity is brand loyalty. This method of measuring consumer loyalty can describe consumer actions whether to switch to another brand or not, especially when a brand experiences changes in price, design, and others. Based On 
Manojkumar and Sharma (2018), willingness to repeat the purchase activity create trust among customer.

\section{Perceived quality}

Quality is essentially the consumer's driver since the customer takes the ultimate decision on the market about the quality of the goods. According to Karina (2015), Perceived quality is the perception of the quality of a good or service by the consumer. It is the desired result or comparing their perception of the quality of competitor's products. According to Saputro (2015), the notion of perceived quality can be interpreted as consumers' understanding of overall quality or the relative superiority of a product or service to alternative products in the same category according to the goals to be achieved. Therefore, it is not possible to determine perceived quality objectively because these perceptions of quality are perceptions that are influenced by things that are important to each customer.

\section{Country of Origin}

Saeed in Alam (2018) stated that Country of origin means the country where the product or manufacturer's brand is associated with the so-called 'home country' in International Business. Several other researchers said the image of the Country of origin is usually used as a general perception of consumers about the quality of products originating from that Country (Kotler, 2010; Gabriella \& Sonny, 2021), while others view it as a definition of beliefs about the industrialization of a country and standard national quality (Srikatanyoo \& Gnoth, 2002; Sharokh \& Azodi. 2013) Thus, the Country in which a product is made can influence buyers' impression of the product.

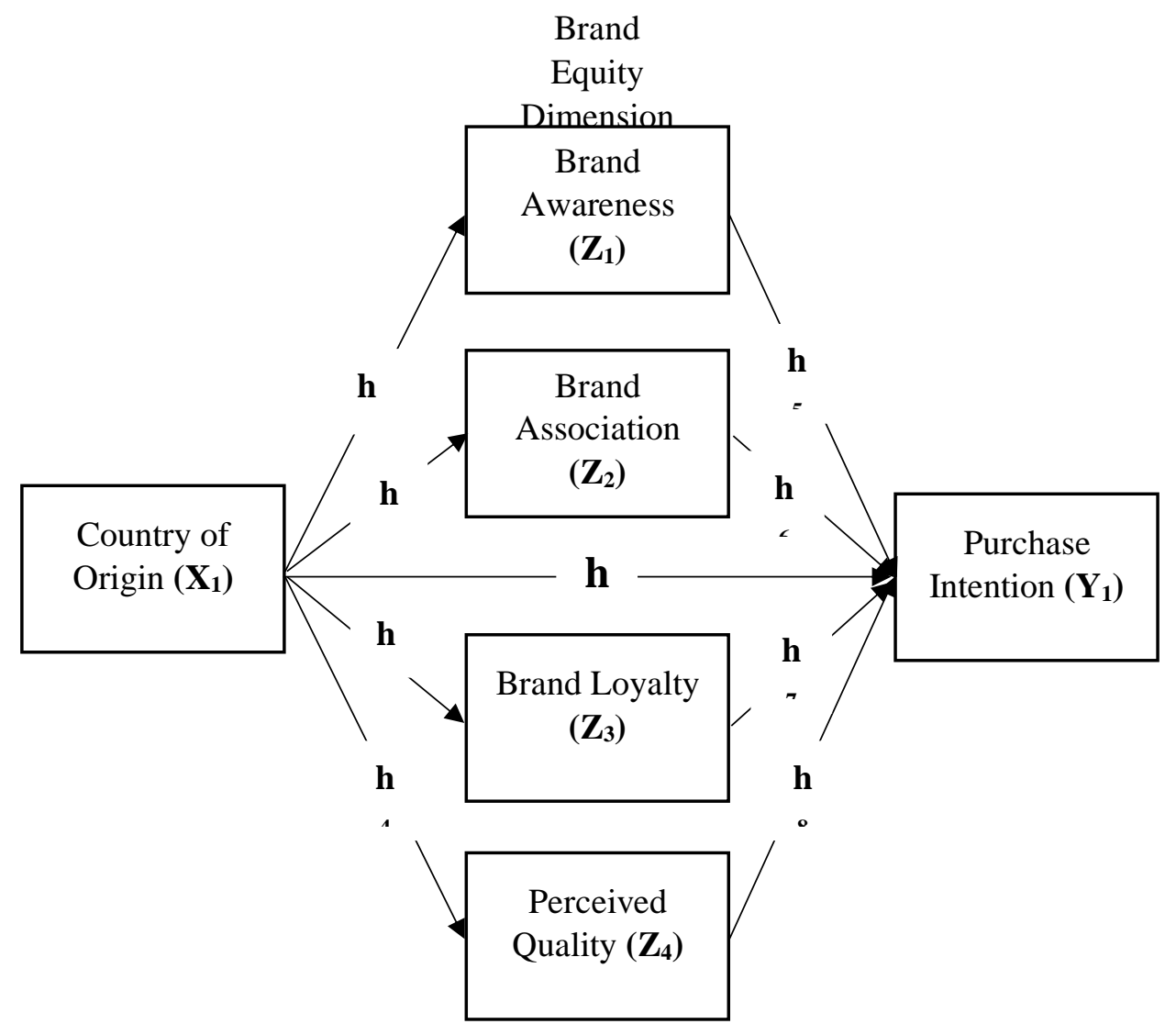

Figure 2.2 Research Model

Source: adapted from Shahrokh and Azodi (2013) 


\section{RESEARCH METHOD}

The method used in this research is the quantitative method. The data to be tested in this study will be collected directly from the field by researchers. The authors' used previous research to explain Country of origin (Alam, 2018), Brand awareness (Sanfilipo, 2017), Brand association (Kotler and Keller, 2012), Brand loyalty (Artaji, 2014), Perceived quality (Karina, 2015), and purchase intention (Manojkumar et al., 2018; Almohaimed, 2018; Liu and Wang, 2019). The population of this Indonesian research citizen who has used Chinese smartphones and lives in the large city of Jakarta. This study uses the convenience sampling method. This means the researcher selects the respondent that is more readily accessible since the chance to anticipate is not equivalent for all eligible individuals in the target population.

Roscoe (1982) proposed that the sample size in the study should be between 30-500 samples. If the research model is multivariate, such as in correlation or multiple regression research, the number of possible participants should be at least ten times the amount of variables tested. (Roscoe, 1982). Since this research is multivariate research with five independent variables and one dependent variable, the minimum number of a sample that used in this sample is $6 \times 10=$ 60. The questionnaire was distributed to 393 people, and of the respondent, 302 respondents met the criteria. The researcher provides questions that will be answered by the respondent using a scale that intended to explain how strong the respondents approve with the five-point scale argument called the Likert scale (Sekaran and Bougie, 2016).

According to Sarwono \& Narimawati (2015), compared to path analysis, factor analysis, and covariance analysis, SEM is used as a stronger alternative method, and SEM has features that can be used for analysis. Based on Jokhu and Armando (2019), partial least square (PLS) can be used to measure path analysis from the $\mathrm{X}-\mathrm{Y}-\mathrm{Z}$ relationship. In this research, hypothesis testing uses techniques of Structural Equation Model (SEM) analysis based on partial least squares (PLS), including outer and inner model.

\section{RESULTS AND DISCUSSION}

Table 4.1

Source: Questionnaire

\begin{tabular}{lll}
\hline & Total & Persentase (\%) \\
\hline Gender & 124 & $41.1 \%$ \\
Pria & 178 & $58.9 \%$ \\
Wanita & & \\
\hline Age & 56 & $18.5 \%$ \\
$\leq 20$ & 127 & $42.1 \%$ \\
$21-30$ & 61 & $20.2 \%$ \\
$31-40$ & 41 & $13.6 \%$ \\
$41-50$ & 17 & $5.6 \%$ \\
$>50$ & & \\
\hline Occupation & 94 & $31.1 \%$ \\
Student & 138 & $45.7 \%$ \\
Employee & 18 & $6 \%$ \\
Entrepreneur & 9 & $3 \%$ \\
Civil servants & 43 & $14.2 \%$ \\
Others & & \\
\hline Monthly Income & 84 & $27.8 \%$ \\
$\leq 1.000 .000$ & 96 & $31.8 \%$ \\
$1.000 .001-5.000 .000$ & 91 & $30.1 \%$ \\
5.000.001 - 10.000.000 & 31 & $10.3 \%$ \\
$>10.000 .000$ &
\end{tabular}


From the table above, it can be seen that the majority of the respondent in this research were female, with 178 respondents (58.9\%) and followed by male with 124 respondents $(41.1 \%)$. It is shown that most of the respondent is $21-30$ years old with 127 respondents $(42.7 \%)$. They were followed by $\leq 20$, with 56 respondents $(18.5 \%)$. It can be seen that most of the respondents of this research are a private employee with 138 respondents $(45 \%)$ followed by a student with 94 respondents $(31.1 \%)$, an entrepreneur with 18 respondents $(6 \%)$, civil servant sith 9 respondents (3\%), and the rest is others occupations. Most of the respondent of this research have a monthly income in the range of 1.000.001 - 5.000.000 with 96 respondents (31.8\%), followed by $5.000 .001-10.000 .000$ with 91 respondents $(30.1 \%), \leq 1.000 .000$ with 84 respondents $(27.8 \%)$, and the rest are above 10.000.000 with 31 respondents (10.3).

To perform data analysis, researchers used a structural equation model assisted by SmartPLS 3.0. to consider every indicator and variable in this research are valid, it can be seen from the Average Variance Extracted (AVE) must be higher than 0.5, and the loading factor value has to be greater than 0.7 (Sarwono \& Narimawati, 2015). To consider every variable in this research is reliable, it can be seen that the value of composite reliability has to be bigger than 0.7 (Sarwono \& Narimawati, 2015). The validity and reliability test result of this research can be seen in table 4.2

Table 4.2

Source : SmartPLS

\begin{tabular}{|c|c|c|c|c|}
\hline & Indikator & $\begin{array}{l}\text { Loading } \\
\text { Factor }\end{array}$ & $\begin{array}{l}\text { Composite } \\
\text { Reliability }\end{array}$ & $\begin{array}{l}\text { Average Variance } \\
\text { Extracted }\end{array}$ \\
\hline \multirow[t]{5}{*}{ Country of Origin } & COO1 & 0.762 & 0.888 & 0.615 \\
\hline & $\mathrm{COO} 2$ & 0.775 & & \\
\hline & $\mathrm{COO} 3$ & 0.826 & & \\
\hline & $\mathrm{COO} 4$ & 0.826 & & \\
\hline & $\mathrm{COO5}$ & 0.727 & & \\
\hline \multirow[t]{5}{*}{ Brand Awareness } & BA1 & 0.797 & 0.883 & 0.609 \\
\hline & BA2 & 0.752 & & \\
\hline & BA3 & 0.876 & & \\
\hline & BA4 & 0.758 & & \\
\hline & BA5 & 0.710 & & \\
\hline \multirow{5}{*}{ Brand Association } & BAS1 & 0.822 & 0.914 & 0.698 \\
\hline & BAS2 & 0.840 & & \\
\hline & BAS3 & 0.883 & & \\
\hline & BAS4 & 0.827 & & \\
\hline & BAS5 & 0.804 & & \\
\hline \multirow[t]{5}{*}{ Brand Loyalty } & BL1 & 0.886 & 0.942 & 0.755 \\
\hline & BL2 & 0.899 & & \\
\hline & BL3 & 0.882 & & \\
\hline & BL4 & 0.866 & & \\
\hline & BL5 & 0.810 & & \\
\hline \multirow[t]{5}{*}{ Perceived Quality } & PQ1 & 0.891 & 0.938 & 0.739 \\
\hline & PQ2 & 0.882 & & \\
\hline & PQ3 & 0.845 & & \\
\hline & PQ4 & 0.895 & & \\
\hline & PQ5 & 0.779 & & \\
\hline \multirow[t]{3}{*}{ Purchase Intention } & PI1 & 0.889 & 0.940 & 0.739 \\
\hline & $\mathrm{PI} 2$ & 0.907 & & \\
\hline & PI3 & 0.758 & & \\
\hline
\end{tabular}




\begin{tabular}{lll}
\hline & PI4 & 0.879 \\
\cline { 2 - 3 } & PI5 & 0.858 \\
\hline
\end{tabular}

According to the research of Abdillah and Jogiyanto (2015), a structural model that is used to forecast causal interactions within latent variables is the structural model (inner model). Path coefficient is used to evaluate the structure of the model in this study, along with the coefficient of determination (R2). This test is used to see and confirm the correlation among variables that are built (Jogiyanto, 2009).

Table 4.3

\begin{tabular}{ll}
\multicolumn{2}{c}{ Source: SmartPLS } \\
\hline Variables & $\begin{array}{l}\text { Coefficient of } \\
\text { Determination }\left(\boldsymbol{R}^{2}\right)\end{array}$ \\
\hline Brand Awareness & 0.202 \\
\hline Brand Association & 0.330 \\
\hline Brand Loyalty & 0.156 \\
\hline Perceived Quality & 0.367 \\
\hline Purchase Intention & 0.801 \\
\hline
\end{tabular}

Referring to Table 4.3, it can be shown that the brand awareness variable's R-Square value is 0.202 . This value indicates that $20 \%$ of brand awareness can be interpreted by the Country of origin, while other factors not analyzed in this analysis can explain the remainder. The brand association variable's R-Square value is 0.330 . This value indicates that $33 \%$ of brand association can be interpreted by the Country of origin, while other factors not analyzed in this analysis can explain the remainder. The brand loyalty variable's R-Square value is 0.156 . This value indicates that $15.6 \%$ of brand loyalty can be interpreted by the Country of origin, while other factors not analyzed in this analysis can explain the remainder. The perceived quality variable's R-Square value is 0.367 . This value indicates that $36.7 \%$ of perceived quality can be interpreted by the Country of origin, while other factors not analyzed in this analysis can explain the remainder. The purchase intention variable's R-Square value is 0.801 . This value indicates that Country of origin, brand awareness, brand association, brand loyalty, and perceived quality can explain purchase intentions by $80.1 \%$ and $19.9 \%$, which are explained by other variables not examined in this study.

Table 4.4

Seource: SmartPLS

\begin{tabular}{llll}
\hline Hypotheses & T Statistics & $\boldsymbol{P}$ Values & Result \\
\hline Country of Origin $\rightarrow$ Brand Awareness & 8.559 & 0.000 & ACCEPTED \\
\hline Country of Origin $\rightarrow$ Brand Association & 11.701 & 0.000 & ACCEPTED \\
\hline Country of Origin $\rightarrow$ Brand Loyalty & 6.934 & 0.000 & ACCEPTED \\
\hline Country of Origin $\rightarrow$ Perceived Quality & 13.290 & 0.000 & ACCEPTED \\
\hline Brand Awareness $\rightarrow$ Purchase Intention & 4.016 & 0.000 & ACCEPTED \\
\hline Brand Association $\rightarrow$ Purchase Intention & 1.326 & 0.185 & REJECTED \\
\hline Brand Loyalty $\rightarrow$ Purchase Intention & 12.327 & 0.000 & ACCEPTED \\
\hline Perceived Quality $\rightarrow$ Purchase Intention & 4.934 & 0.000 & ACCEPTED \\
\hline Country of Origin $\rightarrow$ Purchase Intention & 0.002 & 0.999 & REJECTED \\
\hline
\end{tabular}

The next step is to measure for each relationship path; if the t statistic is greater than 1.96 (5\% significance level) and P-value is lower than 0.05 , then the hypothesis is accepted. The value of $\mathrm{t}$ statistics and $\mathrm{p}$ values can be obtained by bootrsaping in SmartPLS.

From table 4.4, it is known that the P-value which forms the influence of the Country of Origin towards Brand Awareness is $0.000(<0.05)$, while the T-Statistics value is greater than 1.96 (8.559). Therefore, $\mathbf{H 1}$ is accepted. From Table 4.4, it is known that the P-value which forms 
the influence of the Country of Origin towards Brand Association is $0.000(<0.05)$, while the TStatistics value is greater than 1.96 (11.701). Therefore, $\mathbf{H 2}$ is accepted. From Table 4.4, it is known that the P-value which forms the influence of the Country of Origin towards Brand Loyalty is $0.000(<0.05)$, while the T-Statistics value is greater than $1.96(6.934)$. Therefore, $\mathbf{H 3}$ is accepted. From Table 4.4, it is known that the P-value which forms the influence of the Country of Origin towards Perceived Quality is $0.000(<0.05)$, while the T-Statistics value is greater than 1.96 (13.290). Therefore, $\mathbf{H 4}$ is accepted. From Table 4.4, it is known that the Pvalue which forms the influence of the Brand Awareness towards Purchase Intention is 0.000 $(<0.05)$, while the T-Statistics value is greater than 1.96 (4.016). Therefore, H5 is accepted.

From Table 4.4, it is known that the P-value which forms the influence of the Brand Association towards Purchase Intention is $0.185(>0.05)$, while the T-Statistics value is less than 1.96 (1.326). Therefore, H6 is rejected. From Table 4.4, it is known that the P-value which forms the influence of the Brand Loyalty towards Purchase Intention is $0.000(<0.05)$, while the TStatistics value is greater than 1.96 (12.327). Therefore, $\mathbf{H 7}$ is accepted. From Table 4.4, it is known that the P-value which forms the influence of the Perceived Quality towards Purchase Intention is $0.000(<0.05)$, while the T-Statistics value is greater than 1.96 (4.934). Therefore, H8 is accepted. From Table 4.4, it is known that the P-value which forms the influence of the Country of Origin towards Purchase Intention is $0.999(>0.05)$, while the T-Statistics value is less than 1.96 (0.002). Therefore, $\mathbf{H 9}$ is rejected.

\section{CONCLUSION AND RECOMMENDATION}

Through this research, the purchase intention of Xiaomi smartphone customers based on the Country of origin and brand equity can be predicted and determined. Country of origin, brand awareness, brand association, brand loyalty, and perceived quality are variables used to measure the purchase intention of Xiaomi smartphone customers. This study aims to determine the variables that significantly influence purchase intention. This research is a quantitative method using 302 respondents and SmartPLS as a tool to analyzing the data.

Based on the finding of this research, there are 7 hypotheses accepted and 2 hypotheses that rejected. This research found that Country of origin influence all of the brand equity dimensions. It means that the image of China as the Country of origin of Xiaomi affected the perception and impression of Indonesian citizen toward the Xiaomi brand. The result also found that the brand equity dimension (exclude brand association) affect the purchase intention of Xiaomi. The company have to make sure that their brand is well-known by the market in order to increase the purchase intention of the brand. The company also have to make sure that their product has a good perception by the markets so that can increase the intention to purchase.

The researcher found that brand association does not affect purchase intention significantly. It can happen because Xiaomi as an object of this research is already well-known and have a good perceived quality in Indonesia so that the buyer's concern about the other factor associated with the brand becomes lesser. The researcher also found that Country of origin does not affect the purchase intention significantly. Most consumers in Indonesia Most consumers in Indonesia have an opinion that Xiaomi smartphones already have a good and quality image. Besides, respondents in this study are generally adults and already understand smartphones because they have used smartphones, especially smartphones from China. This reason is in line with Purwanto \& Wibisono (2019) research that the image of the Country of origin does not affect purchase intention. Because of the high degree of product information, when purchasing goods, buyers do not even concern about the reputation of the Country of origin. 
This research only analyzed one product from one Country of origin. In future research, it is better to examine more than one brand from different countries to get results that can be highlighted. In future research, it is hoped that it can be applied to other research objects or areas in order to strengthen the external validity of the research. Future analysis is expected to choose other variables not discussed in this research.

\section{REFERENCES}

Aaker, D. A., \& Equity, M. B. (1991). Capitalizing on the Value of a Brand Name. New York, 28(1), 35-37.

Abdillah, W. (2015). Jogiyanto. (2015). Partial least square (PLS) alternatif structural equation modeling (SEM) dalam Penelitian Bisnis, 225-255.

Alam, S. S., Senik, Z. C., Omar, N. A., \& Ali, M. H. (2018). Consumer-based brand equity: Relationship between country of origin and brand equity dimension. Jurnal Pengurusan (UKM Journal of Management), 53.

Almohaimmeed, B. M. (2019). The Effects of Social Media Marketing Antecedents on Social Media Marketing, Brand Loyalty and Purchase Intention: A Customer Perspective. Journal of Business and Retail Management Research, 13(4).

Artaji. (2014). Pengaruh Ekuitas Merek Terhadap Minat Pembelian. Jurnal Fakultas Ekonomi Universitas Negeri Yogyakarta, 11-34.

Berlianto, M. P. (2019). Pengaruh Country of Oringin Dan Brand Image Terhadap Brand Equity Dan Niat Pembelian Pada Produk Kosmetik. Journal of Business \& Applied Management, 12(01).

Indonesia Smartphone Market Sales Register 20\% YoY Decline in Q2 2020, Online Market Share Hits All-time High of 19\%. (2020). Retrieved from https://www.counterpointresearch.com/: https://www.counterpointresearch.com/indonesiasmartphone-market-q2-2020/

Gabriella, G., \& Sonny, S. (2021). The Impact Of Brand Equity To Purchase Intention (Case Study From Iphone Users In Makassar). Jurnal Muara Ilmu Ekonomi dan Bisnis, 5(1), 111.

Jogiyanto, H. M., \& Abdillah, W. (2009). Konsep dan aplikasi PLS (Partial Least Square) untuk penelitian empiris. BPFE Fakultas Ekonomika dan Bisnis UGM. Yogyakarta.

Jokhu, J. R., \& Armando, A. (2019). Perspektif Baru dalam Teori Kualitas Pelayanan: Pentingnya Intensi Studi pada Perusahaan Fintech di Indonesia. Manajemen Bisnis Kompetensi, 13(2).

Karina, N. (2015). The Influence of Brand Equity toward Purchase Intention (A Case Study: Karstu AS GSM Sim Card Provider among the Students at President University). Doctoral Dissertation, President University.

Keller, K. L. (1993). Conceptualizing, measuring, and managing customer-based brand equity. Journal of marketing, 57(1), 1-22.

Kotler, P., \& Keller, K. L. (2012). Marketing Management 14E. New Jersey: Pearson Prentice Hall.

Kreppel, H., \& Holtbrügge, D. (2012). The perceived attractiveness of Chinese products by German consumers-A sociopsychological approach. Journal of Global Marketing, 25(2), 79-99.

Liu, H. H., \& Wang, Y. N. (2019). Interrelationships between viral marketing and purchase intention via customer-based brand equity. Journal of Business and Management Sciences, 7(2), 72-83. 
Manojkumar, S. S., \& Sharma, D. M. S. (2018). An Empirical Study to Measure the Effect of Brand Loyalty and Skepticism on Purchase Intention with Reference to Cause Related Marketing in Ahmedabad City. Journal of Management, 5(2).

Menon, V. P., \& Barani, G. (2016). Dimensions of brand equity: An investigation on higher education institutions. Asian Journal of Research in Social Sciences and Humanities, 6(5), 353-359.

Purwanto, E., \& Wibisono, A. (2019). Pengaruh Country of Origin, Word of Mouth, Kualitas Yang Dipersepsikan Terhadap Niat Beli: Study Pada Kamera Digital Merek Jepang. Jurnal Riset Manajemen dan Bisnis (JRMB) Fakultas Ekonomi UNIAT, 4(3), 365-374.

Roscoe, B. A., Hopke, P. K., Dattner, S. L., \& Jenks, J. M. (1982). The use of principal component factor analysis to interpret particulate compositional data sets. Journal of the Air Pollution Control Association, 32(6), 637-642.

Sarwono, J., \& Narimawati, U. (2015). Membuat Skripsi, Tesis, dan Disertasi dengan Partial Least Square SEM (PLS-SEM). Yogyakarta: ANDI.

Sekaran, U., \& Bougie, R. (2016). Research methods for business: A skill building approach. John Wiley \& Sons.

Shahrokh, Z. D., \& Azodi, A. D. (2013). The effect of country of origin image on brand equity and purchase intention. Journal of Applied Environmental and Biological Sciences, 3(12), 52-61.

Smartphone. (2021). Retreived from computerhope.com: https://www.computerhope.com/jargon/s/smartphone.htm

Srikatanyoo, N., \& Gnoth, J. (2002). Country image and international tertiary education. Journal of Brand Management, 10(2), 139-146.

Usman, O., \& Aryani, Y. (2019). The Effect of Brand Ambassador, Brand Image, Product Quality, and Price on Purchase Intention. Brand Image, Product Quality, and Price on Purchase Intention (December 31, 2019).

Wicaksana, S. N. (2018). Analisis Perbedaan Persepsi Konsumen terhadap Merek Smartphone China dan non China. Universitas Sanata Dharma, obtained from: http://repository.usd.ac.id/31371/2/142214202_full.pdf

Yunus, N. S. N. M., \& Rashid, W. E. W. (2016). The influence of country-of-origin on consumer purchase intention: The mobile phones brand from China. Procedia Economics and Finance, 37, 343-349. 